Review

\title{
Calcium in Red Blood Cells_-A Perilous Balance
}

\section{Anna Bogdanova ${ }^{1}$, Asya Makhro ${ }^{1}$, Jue Wang ${ }^{2}$, Peter Lipp ${ }^{2}$ and Lars Kaestner ${ }^{2, *}$}

1 Institute of Veterinary Physiology, Vetsuisse Faculty and the Zürich, Center for Integrative Human Physiology, University of Zürich, Zürich 8057, Switzerland;

E-Mails: annab@access.uzh.ch (A.B.); makhro@vetphys.uzh.ch (A.M.)

2 Institute for Molecular Cell Biology and Research Centre for Molecular Imaging and Screening, Saarland University, Homburg/Saar 66421, Germany;

E-Mails: jue.wang@uniklinikum-saarland.de (J.W.); peter.lipp@uks.eu (P.L.)

* Author to whom correspondence should be addressed; E-Mail: lars_kaestner@me.com; Tel.: +49-6841-16-26103; Fax: +49-6841-16-26104.

Received: 27 February 2013; in revised form: 18 March 2013 / Accepted: 19 March 2013 / Published: 8 May 2013

\begin{abstract}
Ca}^{2+}$ is a universal signalling molecule involved in regulating cell cycle and fate, metabolism and structural integrity, motility and volume. Like other cells, red blood cells (RBCs) rely on $\mathrm{Ca}^{2+}$ dependent signalling during differentiation from precursor cells. Intracellular $\mathrm{Ca}^{2+}$ levels in the circulating human RBCs take part not only in controlling biophysical properties such as membrane composition, volume and rheological properties, but also physiological parameters such as metabolic activity, redox state and cell clearance. Extremely low basal permeability of the human $\mathrm{RBC}$ membrane to $\mathrm{Ca}^{2+}$ and a powerful $\mathrm{Ca}^{2+}$ pump maintains intracellular free $\mathrm{Ca}^{2+}$ levels between 30 and $60 \mathrm{nM}$, whereas blood plasma $\mathrm{Ca}^{2+}$ is approximately $1.8 \mathrm{mM}$. Thus, activation of $\mathrm{Ca}^{2+}$ uptake has an impressive impact on multiple processes in the cells rendering $\mathrm{Ca}^{2+}$ a master regulator in $\mathrm{RBCs}$. Malfunction of $\mathrm{Ca}^{2+}$ transporters in human RBCs leads to excessive accumulation of $\mathrm{Ca}^{2+}$ within the cells. This is associated with a number of pathological states including sickle cell disease, thalassemia, phosphofructokinase deficiency and other forms of hereditary anaemia. Continuous progress in unravelling the molecular nature of $\mathrm{Ca}^{2+}$ transport pathways allows harnessing $\mathrm{Ca}^{2+}$ uptake, avoiding premature $\mathrm{RBC}$ clearance and thrombotic complications. This review summarizes our current knowledge of $\mathrm{Ca}^{2+}$ signalling in RBCs emphasizing the importance of this inorganic cation in RBC function and survival.
\end{abstract}


Keywords: erythrocyte; senescence; clot formation; thrombosis; cytoskeleton

\section{Introduction}

$\mathrm{Ca}^{2+}$ is a universal and ubiquitous signalling molecule [1,2], regulating cell cycle and fate, metabolism and structural integrity, motility and volume. Most of the $\mathrm{Ca}^{2+}$ in the cytosol is bound and buffered by numerous $\mathrm{Ca}^{2+}$ binding proteins, phospholipids and inorganic phosphate. When bound and buffered $\mathrm{Ca}^{2+}$ are included, total intracellular $\mathrm{Ca}^{2+}$ in red blood cells (RBCs) reaches 5.7 $\mu \mathrm{M}$ [3]. Basal free $\mathrm{Ca}^{2+}$ concentration in RBCs of healthy human beings under physiological conditions is estimated to be in the range of 30 to $60 \mathrm{nM}$ [4]. A tremendous gradient of at least 40,000-fold between the cytosol and blood plasma where free $\mathrm{Ca}^{2+}$ concentration reaches up to $1.8 \mathrm{mM}$ is maintained due to particularly low permeability of membranes to $\mathrm{Ca}^{2+}\left(\sim 50 \mu \mathrm{mol} /\left(1_{\text {cells }} \mathrm{h}\right)\right)$ and efficient extrusion of $\mathrm{Ca}^{2+}$ from the cells by the plasma membrane $\mathrm{Ca}^{2+}$ pump (PMCA) [4]. This gradient may be used for signalling purposes as opening of a few hundreds of channels transporting $10^{6}$ ions per second over several milliseconds may result in $>10$-fold changes in free $\mathrm{Ca}^{2+}$ levels in the sub-membrane space, causing acute changes in the activity of multiple $\mathrm{Ca}^{2+}$ sensitive proteins involved in structural, signalling, metabolic and transport functions. Such a huge $\mathrm{Ca}^{2+}$ influx seems to exceed the RBC's $\mathrm{Ca}^{2+}$-buffering abilities. Long-term increases in the $\mathrm{Ca}^{2+}$ permeability result in serious dysregulation of multiple cellular functions. The subsequent onset of proteolysis, oxidation, irreversible shrinkage and phosphatydylserine (PS) exposure to the extracellular membrane leaflet facilitate clearance of $\mathrm{Ca}^{2+}$ overloaded cells in case the latter have not been haemolysed when passing through capillaries.

This review summarizes the current knowledge on the regulation of $\mathrm{RBC} \mathrm{Ca}{ }^{2+}$ levels, $\mathrm{Ca}^{2+}$ dependent processes and the potential role that $\mathrm{Ca}^{2+}$ might play in the development of $\mathrm{RBC}$ pathologies. For obvious reasons this review makes no claim to be complete, but wants to draw attention to open questions and mechanisms to be resolved in the field of $\mathrm{Ca}^{2+}$ signalling in $\mathrm{RBCs}$.

\section{2. $\mathrm{Ca}^{2+}$ Transport across the $\mathrm{RBC}$ Membrane}

\section{1. $\mathrm{Ca}^{2+}$ Extrusion Pathway: Plasma Membrane $\mathrm{Ca}^{2+}$ Pump}

It was realised very early on that the inhibition of the energy supply in RBCs leads to a $\mathrm{Ca}^{2+}$ increase [5]. Although the nature of the $\mathrm{Ca}^{2+}$ influx remained unknown for several decades, the extrusion mechanism was realized to be mediated by a plasma membrane $\mathrm{Ca}^{2+}$ pump (PMCA). For human RBC membrane the presence of the B-splice isoform of the PMCA1 was shown [6]. This P-type ATPase is ubiquitously expressed. It is composed of 1220 amino acids forming ten transmembrane domains, two intracellular loops containing ATP binding and phosphorylation sites and inward-facing $\mathrm{N}$ - and $\mathrm{C}$-terminals. The latter contains a $\mathrm{Ca}^{2+}$ calmodulin binding domain, phosphorylation sites and a PDZ-binding domain serving as a docking terminal for a number of proteins [7]. The maximal $\mathrm{Ca}^{2+}$ extrusion rate in $\mathrm{RBCs}$ can vary within $\mathrm{RBC}$ populations of a single donor between $>60 \mathrm{mmol} /\left(1_{\text {cells }} \mathrm{h}\right)$ and $<4 \mathrm{mmol} /\left(1_{\text {cells }} \mathrm{h}\right)$ [8]. The maximal turnover rate of the PCMA is significantly higher in RBCs from light fractions compared to that in RBCs within dehydrated RBC 
fractions following density centrifugation [9]. This reduction in $V_{\max }$ in cells from the dense fraction was referred to as a hallmark of $\mathrm{RBC}$ senescence [10]. The maximal $\mathrm{Ca}^{2+}$ turnover rate of PMCA in the RBC membrane of healthy humans not loaded with $\mathrm{Ca}^{2+}$ is most likely never reached. The apparent $V_{\max }$ for PMCA measured in such cells is $\sim 50 \mu \mathrm{mol} /\left(1_{\text {cells }} \mathrm{h}\right)$, the value equal to the passive $\mathrm{Ca}^{2+}$ uptake. The enzyme half-activation constant for $\mathrm{Ca}^{2+}$ was reported to be $4 \mu \mathrm{M}$, far above the actual free cytosolic $\mathrm{Ca}^{2+}$ levels in human RBCs [11].

Increases in the intracellular free $\mathrm{Ca}^{2+}$ are sensed by the PMCA and occur in response to the interaction of the $\mathrm{Ca}^{2+}$ calmodulin complex with the $C$-terminus of the enzyme. In $\mathrm{Ca}^{2+}$-loaded $\mathrm{RBCs}$ the limiting factor of the PMCA transport capacity is ATP availability. The pump is fuelled preferentially by a pre-membrane ATP pool $[8,12,13]$ and has a $K_{\mathrm{d}}$ (ATP) of $145 \mu \mathrm{M}[5,14]$. Under conditions of permanent $\mathrm{Ca}^{2+}$ leak, activation of PMCA results in rapid ATP depletion.

RBC-derived plasma membrane vesicles contain factors activating PMCA, such as arachidonic acid, ceramide and acidic phospholipids, whereas sphingosine suppresses its function [15-17]. The function of the PMCA is extremely temperature-sensitive with $\sim 30$-fold reduction in turnover rate for every $10{ }^{\circ} \mathrm{C}$ drop [18].

\section{2. $\mathrm{Ca}^{2+}$ Influx Pathways}

$\mathrm{Ca}^{2+}$ influx through the plasma membrane of healthy human RBCs is extremely slow but increasing up-to 5-fold in cells of patients with sickle cell disease (SCD) and several other forms of hereditary haemolytic anaemia [4]. Several cation channels mediate inward movement of $\mathrm{Ca}^{2+}$. Significant progress in identification of ion channels in control of $\mathrm{Ca}^{2+}$ uptake has recently been reviewed [19].

Voltage-activated non-selective cation channels [20-22] were shown to be $\mathrm{Ca}^{2+}$ permeable [23]. These initial observations have all been performed on excised patches, but the presence of the channel was also shown in the whole cell configuration [24] and further flux-based characterisations have been performed [25-27]. However, a proof of the molecular identity remains to be provided.

Furthermore, a P-type $\mathrm{Ca}^{2+}$ channel was pharmacologically identified [28] and shown to be a Cav2.1 channel by Western blot analysis [29]. This channel can be inhibited by $\omega$-agatoxin TK [29]. However, in contrast to the initial investigations, in which activation by protein kinase $\mathrm{C}$ (PKC) was proposed, recent findings depicted a rather indirect interaction with PKC [30].

A recent report provided evidence for the presence of a transient receptor potential (TRP) channel of subtype C6 in the RBC membrane [31]. However, most of the work done so far was performed on murine RBCs and detailed characterization of this channel in human RBCs is missing.

In addition, the expression of an NMDA receptor channel was initially reported for rat [32] and later in human RBCs using molecular biological and electrophysiological approaches [33]. NMDA receptor agonists include glutamate, $N$-methyl D-aspartate (NMDA), homocysteine, homocysteic acid, glycine and D-serine [34].

Recently, the protein PIEZO1 was reported as being mutated in RBCs in hereditary xerocytosis [35] without knowing its physiological function. However, PIEZO1 is characterized as a mechano-sensitive cation channel in heterologous expression systems [36,37].

Furthermore there is evidence for an AMPA receptor related channel activity in RBCs [38]. 
All the channels mentioned above were reported to be present in human RBCs from healthy donors. However, some currents were only shown to be present in cells of patients. An example is an increase in non-selective cation conductance on RBC of SCD patients mediating or contributing to $\mathrm{P}_{\text {sickle }}[39,40]$, an increased membrane permeability in SCD RBC. It is still not completely clear if this reflects an increased activity of one or more of the above mentioned channels or yet another conductance [40,41]. However, recent investigations provide evidence for the involvement of the NMDA receptor [42].

\section{3. $\mathrm{Ca}^{2+}$-Sensitive Proteins in RBCs}

\subsection{Onset of $\mathrm{Ca}^{2+}$-Inducible Events and $\mathrm{Ca}^{2+}$ Sensors in $\mathrm{RBCS}$}

When in the cell, $\mathrm{Ca}^{2+}$ activates numerous $\mathrm{Ca}^{2+}$ dependent proteins. Each of them has its own activation threshold. Thus, gradual increase in $\mathrm{Ca}^{2+}$ levels is associated with gradual activation of various groups of $\mathrm{Ca}^{2+}$-sensitive proteins involved in physiological and pathophysiological processes in RBCs. In Figure 1 we compiled current knowledge about the activation ranges of some selected proteins. This list of $\mathrm{Ca}^{2+}$ sensitive proteins is by far not comprehensive and can hardly be covered within one review. Despite a large number of such proteins and diversity of their functions, only few of them are "true" $\mathrm{Ca}^{2+}$ sensors interacting directly with calcium ions [43]. One of such ubiquitous sensors highly abundant in RBCs is calmodulin. Calmodulins $1-4(\mathrm{CaM})$ are $17 \mathrm{kDa}$ proteins comprising two globular EF hand $\mathrm{Ca}^{2+}$ binding domains enriched with carboxyl and carbonyl groups (Asp, Glu and Thr) interconnected with a flexible linker (for details see, e.g., [44,45]). Upon interaction with $\mathrm{Ca}^{2+}, \mathrm{CaM}$ wraps around amphipathic regions of the protein compacting into a globular shape and pulling the interacting domains of the target out of lipophilic pockets or out of the membrane lipid bilayer moiety. In RBCs the proteins regulated by interaction with the $\mathrm{Ca}^{2+}$ calmodulin 2 complex (Ca-CaM) include, e.g., elements of the cytoskeletal network, the $\mathrm{Na}^{+} / \mathrm{H}^{+}$exchanger NHE1, PMCA and the endothelial NO synthase (eNOS). Cytoplasmic CaM becomes active when recruited to the plasma membrane where its action is often coupled to that of phosphatidylinositol 4,5-bisphosphate $\left(\mathrm{PIP}_{2}\right)$ localised at the inner leaflet of the membrane. An example of such coupling is a competitive binding of both co-regulators to the intracellular domain of NHE1 (see Figure 2A).

Another class of "true" $\mathrm{Ca}^{2+}$ sensors ( $\sim 650$ proteins included) contain $\mathrm{Ca}^{2+}$ binding $\mathrm{C} 2$ domains interacting with 2-3 $\mathrm{Ca}^{2+}[43,46]$. In RBCs proteins with $\mathrm{C} 2$ domains include phospholipases, $\mathrm{PKC} \alpha$, phosphoinositide 3-kinase (PI3K) and many others. Binding of $\mathrm{Ca}^{2+}$ to the $\mathrm{C} 2$ domains, triggers translocation of these proteins to the specific areas within plasma membrane containing their substrates [46]. 
Figure 1. Overview of concentration dependence of $\mathrm{Ca}^{2+}$ activated events in RBCs. The yellow column indicates the estimated range of $\mathrm{RBCs}$ ' resting free $\mathrm{Ca}^{2+}[4]$. The gray/black bars indicate the activation of the proteins with the intensity of darkness related to the activation level (details see below). The red lines depict the half activation concentration. For orientation, the green line provides the in vivo $k_{\mathrm{D}}$ for Fluo-4 [47], probably the most appropriate $\mathrm{Ca}^{2+}$ fluorophore to be used in RBCs [48]. The universal intermediate messenger calmodulin has a dissociation constant for $\mathrm{Ca}^{2+}$ of $920 \mathrm{nM}$ [49], which can be shifted down to $100 \mathrm{nM}$ (see main text), indicated by the red arrow. The Gardos channel has an open probability of $\mathrm{EC}_{50}$ of $4.7 \mu \mathrm{M}$ with a Hill slope factor of approximately 1 [50]. Values were measured in excised patches at a membrane potential of $0 \mathrm{mV}$. The curve of the opening frequency is almost superimposable $\left(\mathrm{EC}_{50}\right.$ of $\left.4.3 \mu \mathrm{M}\right)$ [50] keeping the values given in the figure valid also for whole cell and hence population based investigations. The values for half maximal activation of the scramblase were determined by different studies with varying methodologies and a slightly different result. Values varied between approximately $30 \mu \mathrm{M}$ determined in liposomes [51] and $70 \mu \mathrm{M}$ measured in $\mathrm{RBC}$ ghosts [52]. The flippase depicts almost full inhibition already at a $\mathrm{Ca}^{2+}$ concentration of $400 \mathrm{nM}$ [53]. $\mu$-Calpain, a protein that cleaves cytoskeleton and membrane proteins depicts half activation at $40 \mu \mathrm{M} \mathrm{Ca}^{2+}$ [54] but can be activated and then shifting half-maximal activation down to $200 \mathrm{nM}$ [55]. Transglutaminase mediating polymerisation of RBC membrane proteins in its native form has a dissociation constant for $\mathrm{Ca}^{2+}$ of $190 \mu \mathrm{M}$ [56]. Adenosine monophosphate (AMP) deaminase is an enzyme that converts AMP into inosin monophosphate and is directly stimulated by $\mathrm{Ca}^{2+}$ at a half maximal concentration of $50 \mu \mathrm{M}$ free $\mathrm{Ca}^{2+}$ [57]. The binding of $\mathrm{Ca}^{2+}$ to the $\mathrm{C} 2$-domain of $\mathrm{PKC} \alpha$ was determined in vitro to be $35 \mu \mathrm{M}$ with a Hill coefficient of 0.9 [58]. Although the $\mathrm{Ca}^{2+}$ dependence of the membrane binding was measured to be an order of magnitude lower [58], the initial $\mathrm{Ca}^{2+}$ binding is the crucial step for PKC $\alpha$ activation and therefore the relevant number in this compilation.

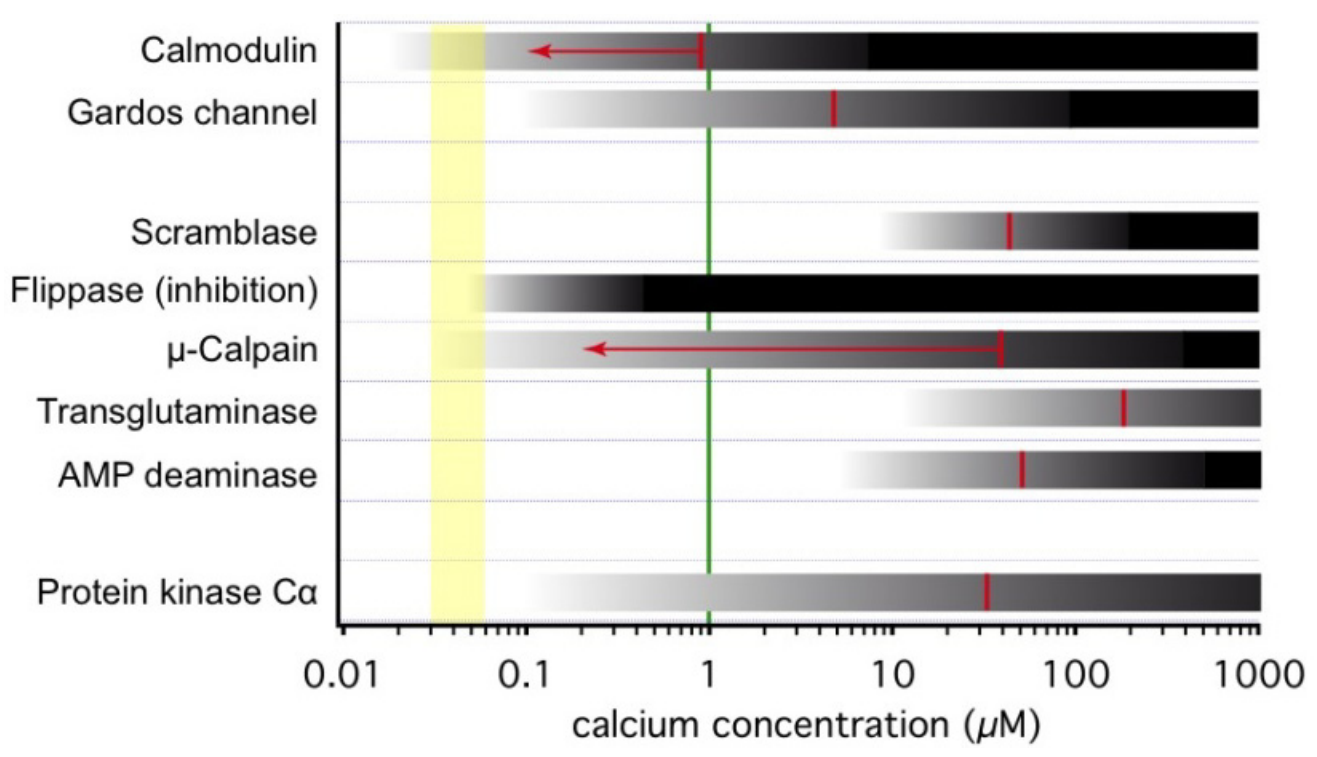


Figure 2. $\mathrm{Ca}^{2+}$ and $\mathrm{RBC}$ cytoskeleton. (A) $\mathrm{Ca}^{2+}$ sensitive elements of the cytoskeleton: band 4.1 and adducin interact with the $\mathrm{Ca}^{2+}$-calmodulin $(\mathrm{Ca}-\mathrm{CaM})$ complex. Adducin binds to actin blocking elongation of the fast-growing (barbing) ends of actin filaments within junctional complexes $(\mathrm{J})$. When interacting with the band 3 dimers anchoring the spectrin network to the membrane, $\mathrm{J}$ become a part of bigger multi-protein complexes known as 4.1R-comples (4.1RC). Interaction with $\mathrm{Ca}-\mathrm{CaM}$ down-regulates capping activity of adducin regulating thereby actin filament assembly [59]. Furthermore, adducin tetramers participate in docking of carbonic anhydrase II (CAII) to band 3 tetrames. NHE1 is activated as it joins CAII and thereby becomes associated with the ankyrin complex (AC) $[60,61]$. Band 4.1R is an interacting partner of a number of proteins. Those include spectrin and actin which bind to the $10 \mathrm{kDa}$ domain of the band $4.1 \mathrm{R}$ protein; band 3 protein, p55, and GPC docking to the FERM domain of it and NHE1 interacting with its $C$-terminal $24 \mathrm{kDa}$ domain. Interaction of band $4.1 \mathrm{R}$ with $\mathrm{Ca}-\mathrm{CaM}$ triggers the reduction of the affinity of this protein to all interacting partners. As a result, spectrin network interaction with the integral proteins becomes loose. Decrease in affinity of band 4.1R to the cytosolic domain of NHE1 favours its dissociation from 4.1R and interaction with phoshatidylinositol 4,5-phosphate $\left(\mathrm{PIP}_{2}\right)$, thus causing NHE activation [62]. $\mathrm{PIP}_{2}$ also modulates interaction of band 4.1R with glycophorin $\mathrm{C}$ and band 3 protein [63]; (B) Schematic representation of the FERM (4.1/ezrin/radixin/moesin) domain of band 4.1 protein, indicating docking ports for interacting partners and $\mathrm{Ca}-\mathrm{CaM}$ binding sites (for details see [64]).

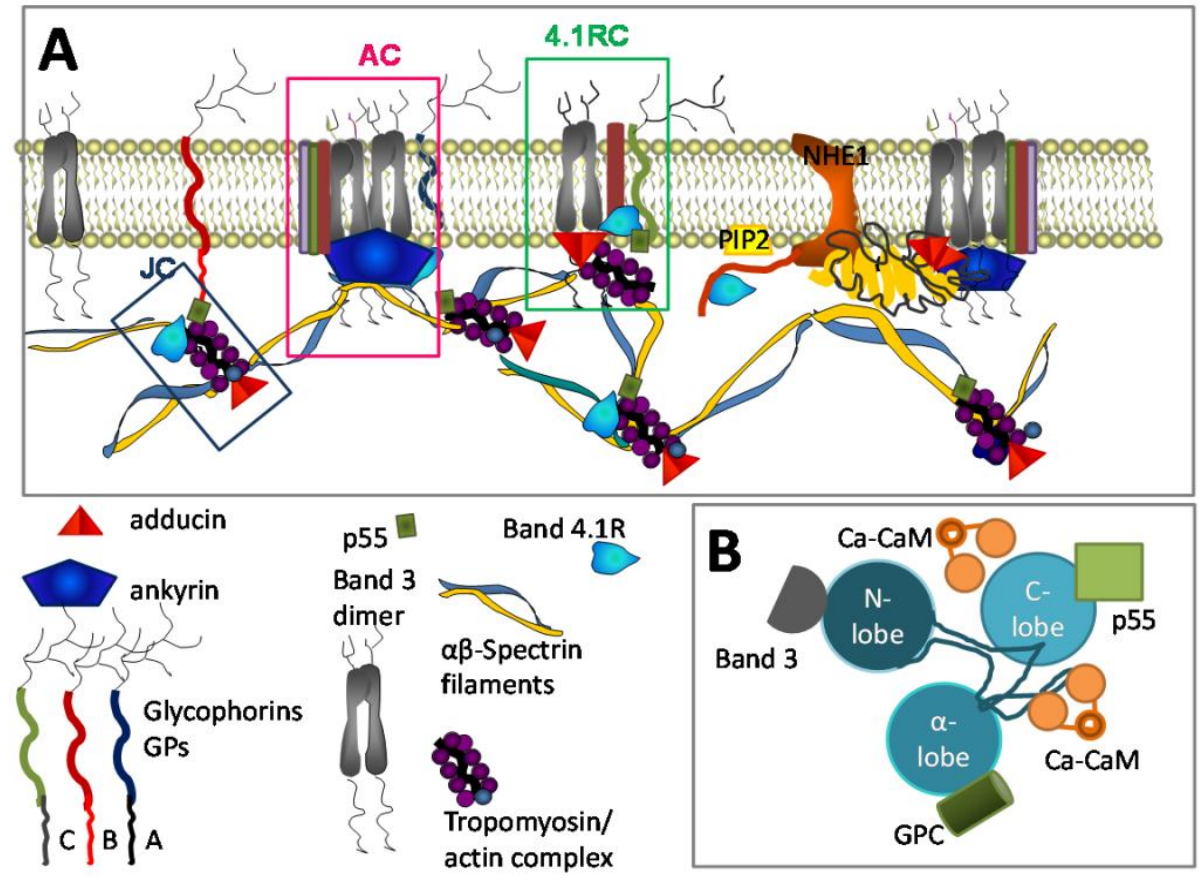

\section{2. $\mathrm{Ca}^{2+}$-Dependent Phosphorylation}

Changes in phosphorylation are among the most important modulations of protein activity in RBCs. Among the kinases there is a group of $\mathrm{Ca}^{2+}$ activated protein kinases, the conventional protein kinase $\mathrm{C}$ (cPKC) [65]. Among cPKCs, only protein kinase $\mathrm{C} \alpha(\mathrm{PKC} \alpha)$ can be found in RBCs [66]. Upon $\mathrm{Ca}^{2+}$ 
binding, PKC $\alpha$ translocates to the plasma membrane, where it phosphorylates its target proteins. The kinase domain of PKCs lacks specificity [67,68] and therefore numerous proteins can be phosphorylated. Reports include the PMCA [69], cytoskeletal proteins ([70,71] and see below), NADPH oxidase [72] and possibly further proteins [29,30,73] are affected.

\section{3. $\mathrm{Ca}^{2+}$ and RBC Cytoskeleton}

Opening of cation channels in response to mechanical stress and the presence of activators, such as amino acids, proinflammatory cytokines and others, result in local transient increase in $\mathrm{Ca}^{2+}$ levels in the vicinity of the plasma membrane. The latter, most likely serves as a signal to mediate rapid reversible changes in cytoskeletal flexibility.

The calcium-calmodulin complex ( $\mathrm{Ca}-\mathrm{CaM})$ plays a key role in regulation of cytoskeletal stability. Selected elements of the cytoskeletal architecture interacting with Ca-CaM are schematically shown in Figure 2 together with their interacting partners. Those include major components of the cytoskeletal network, protein $4.1 \mathrm{R}$, and adducin. These proteins function as docking stations for spectrin and actin, band 3 protein, glycophorins protein 4.2 and p55 and form a complex known as ankyrin-based complex and junctional complex (Figure 2A) [74,75]. The junctional complex is formed by the three principal components of the skeletal network junctions (spectin, actin, and 4.1R, together with tropomyosin, tropomodulin, adducin, dematin, p55). When associated with transmembrane proteins, GPC, XK, Kell, Duffy, band 3, and Rh junction complex forms a multiprotein 4.1R-based complex [76].

It is shown in Figure 2A, that the band 4.1R protein is a key constituent of all three complexes. Upon interaction with $\mathrm{Ca}-\mathrm{CaM}$, affinity of the $4.1 \mathrm{R}$ protein to all the interacting partners decreases and the cytoskeletal structure including spectrin-actin-tropomyosin junctions and the spectrin-actomyosin web interaction with the transmembrane protein clusters becomes loose and unstable. Such, Ca-CaM induced dissociation of NHE1 from the ankyrin complexes and band 4.1R protein. This facilitates the interaction of NHE1 with $\mathrm{PIP}_{2}$ resulting in activation of this ion transporter and dysregulation of cell volume and cytosolic alkalosis [62,77].

The $\mathrm{Ca}^{2+}$ concentration required for half-activation of calmodulin is $100 \mathrm{nM}$ [78]-920 nM [49], Figure 1, thus no significant dissociation of the membrane cytoskeleton is expected to occur under physiological concentration of intracellular free $\mathrm{Ca}^{2+}$ [79]. Phosphorylation of calmodulin at Ser-80 and -84 affects its affinity to $4.1 \mathrm{R}$ reducing their binding [80].

$\mathrm{Ca}^{2+}$ dependent phosphorylation is a second mode of action of $\mathrm{Ca}^{2+}$ on cytoskeletal proteins. Phosphorylation of the 4.1R protein at serine 312 and serine 331 by $\mathrm{PKC}$ was reported [81]. These two phosphorylation sites are localised within a domain flanked by the spectrin- and actin binding domain and a domain containing the interaction sites for transmembrane proteins (Figure 2B). When phosphorylated the 4.1R- $\beta$-spectrin interaction appears to be weakened by $\sim 30 \%$ [81]. As $\mathrm{Ca}^{2+}$ uptake is known to be triggered by mechanical deformations [82], controlled reversible loosening of cytoskeletal network in cells passing through capillaries is an advantage. Uncontrolled irreversible loss of cytoskeletal stability in RBCs of patients with haemolytic anaemia, in which $\mathrm{Ca}^{2+}$ is permanently upregulated, on the contrary compromises mechanical stability of the RBC membrane [83]. In RBCs of healthy humans the 4.1R protein is not phosphorylated [81]. One more target of PKC is $\alpha$-adducin 
which, upon phosphorylation at Ser-726 decreases its affinity to F-actin, as it was observed in SCD RBCs. After the loss of F-actin capping dissociation of spectrin from actin occurs [84], which results in $\mathrm{RBC}$ inability to change shape.

In RBCs transaminase 2 responds to $\mathrm{Ca}^{2+}$ entry with a rapid release of its inhibitory GTP and activation resulting in formation of $\mathrm{N} \varepsilon$ ( $\gamma$-glutaminyl)lysine cross-linking (Figure 1). As a result, in $\mathrm{Ca}^{2+}$ overloaded RBCs formation of numerous polymeric protein complexes such as Glut1-adducin-dematin adducts as well as cross-linked complexes of Band 3-ankyrin-spectrin and glycophorin C-band 4.1-p55 occurs [85]. This $\mathrm{Ca}^{2+}$ induced remodelling of the cytoskeletal structure and concomitant changes in cell shape and membrane plasticity are suggested to contribute to premature RBC clearance.

\section{4. $\mathrm{Ca}^{2+}$ and $\mathrm{RBC}$ Volume Regulation}

RBC volume regulation is a complex process with contributions of numerous molecular players including, e.g., band 3 protein [86]. A marked volume decrease is mediated by the so-called Gardos effect, which was among the first $\mathrm{Ca}^{2+}$ dependent processes recognized in RBCs [87]. The corresponding Gardos channel was the first channel measured by patch-clamp in RBCs $[88,89]$. This channel is a $\mathrm{Ca}^{2+}$ activated $\mathrm{K}^{+}$channel and the Gardos effect represents the $\mathrm{Ca}^{2+}$ induced $\mathrm{K}^{+}$loss of RBCs. The channel is characterized by a single channel conductance of approximately $20 \mathrm{pS}$ [88], a selectivity of $\mathrm{K}^{+}$to $\mathrm{Na}^{+}$of about 15:1 [90] and an $\mathrm{EC}_{50}\left(\mathrm{Ca}^{2+}\right)$ of $4.7 \mu \mathrm{M}$, Figure 1 with a Hill-slope of approximately 1 [50]. Later, the molecular identity of the Gardos channel was shown to be the hSK4 channel [91]. Functionally, the opening of the Gardos channel leads to a hyperpolarisation and a loss of $\mathrm{K}^{+}, \mathrm{Cl}^{-}$and water resulting in cell shrinkage. Although the physiological function of the Gardos channel is not completely elucidated, there are two complementary concepts: (i) Openings of RBC $\mathrm{Ca}^{2+}$ channels by platelet released substances [92,93] initialy trigger the consecutive activation of the Gardos channel. This Gardos channel mediated dehydration of the RBC fosters their contribution in clot formation as outlined below. (ii) Local membrane deformation of RBCs was shown to trigger a transient increase in $\mathrm{Ca}^{2+}$ permeability with secondary activation of the Gardos channels [82]. This was proposed to induce significant dehydration even during a brief deformation event in the microcirculation [82].

\section{5. $\mathrm{Ca}^{2+}$ and Lipid Bilayer}

Scramblase is a protein responsible for bidirectional transmembrane movement of phospholipids [94] leading to the break-down of the originally asymmetrical distribution of phospholipids between the inner and outer membrane leaflet [95]. It is a passive transport, but $\mathrm{Ca}^{2+}$ activated [51,52]. Its $\mathrm{Ca}^{2+}$ sensitivity is mediated by an EF hand motif [96]. The scramblase activity is complemented by the flippase (aminophospholipid translocase) inhibition [97]. This protein actively builds up phospholipid asymmetry and such can be regarded as the opponent of the scramblase. As shown in Figure 1, flippase activity is almost completely suppressed by $400 \mathrm{nM} \mathrm{Ca}^{2+}[53]$. 


\section{6. $\mathrm{Ca}^{2+}$ and Metabolism}

Numerous reports emphasize the possible role of the Ca-CaM system in regulation of activity of glycolytic enzymes including pyruvate kinase $[98,99]$. However, even more important is its pivotal role in assembling the glycolytic enzymes at the RBC membrane. Band 3 protein and its cytosolic domain was shown to serve as a docking station for multiple glycolytic enzymes [100]. $\mathrm{Ca}^{2+}$ in turn was suggested to promote band 3 tyrosine phosphorylation [101]. Phosphorylation of the cytosolic domain of band 3 protein (cdb3) at Tyr9 and Tyr21 results in displacement of LDH, PK, GAPDH, PFK and aldolase from RBC membrane in intact cells [102]. A similar effect is induced by interaction of deoxyHb with band 3 protein [103].

\section{7. $\mathrm{Ca}^{2+}$ and Redox State Preservation}

In RBCs there is a direct link between the intracellular free $\mathrm{Ca}^{2+}$ concentration and the haemoglobin oxygen saturation. In cells of healthy individuals, passive $\mathrm{Ca}^{2+}$ uptake was unaffected by deoxygenation, but the $V_{\max }$ of the PMCA was reduced by $18 \%-32 \%$ [104]. This is not the case in RBCs of patients with SCD [4]. An increase in free $\mathrm{Ca}^{2+}$ levels was mainly attributed to changes in haemoglobin protonation, increases in protonation of deoxyhaemoglobin and a shift in the intracellular pH towards more alkaline values [104,105]. Along with augmentation of 2,3-diphosphoglycerate and ATP binding to haemoglobin, interaction of deoxyhaemoglobin with protons is associated with a decrease in $\mathrm{Ca}^{2+}$ buffering capacity of haemoglobin. In the cytosol of deoxygenated RBCs release of $\mathrm{Ca}^{2+}$ ions from protein binding sites and lowering of extrusion capacity of the PMCA contribute to both an increase in the ionised $\mathrm{Ca}^{2+}$ fraction by $34 \%-74 \%$ even in the absence of $\mathrm{Ca}^{2+}$ influx from the extracellular medium [104].

Increases in the free $\mathrm{Ca}^{2+}$ were recently linked to a lower oxygen affinity of haemoglobin promoting the release of oxygen [33]. Deoxygenation induced transient release of $\mathrm{Ca}^{2+}$ from intracellular buffers may promote further deoxygenation enhancing $\mathrm{O}_{2}$ dissociation from haemoglobin. Molecular mechanisms of this phenomenon remain to be investigated.

Aside to the control of haemoglobin oxygenation, $\mathrm{Ca}^{2+}$ is also involved in the regulation of the RBC's redox state. Ca-CaM complexes are co-activators of endothelial NO synthase (eNOS) activity [106,107]. Recently eNOS was shown to be present in circulating RBCs [108,109] and is activated by $\mathrm{Ca}^{2+}$ uptake during shear stress [82,110]. Nitric oxide is a scavenger of superoxide anions, which interacts with them two orders of magnitude faster than superoxide dismutase (SOD) [111]. However, following shortage of tetrahydrobiopterin or L-arginine eNOS itself gets uncoupled and is capable of generating superoxide anions, which is turned into $\mathrm{H}_{2} \mathrm{O}_{2}$ in a reaction catalysed by SOD [106]. Pro-oxidative action of uncoupled eNOS was demonstrated in RBCs [112].

\subsection{Calpain and Its Targets in RBCs}

While the $\mathrm{Ca}^{2+}$ dependent cysteine protease $\mu$-calpain (calpain-1) was mainly detected in human RBCs, m-calpain (calpain-2) was found to be virtually absent [113]. $\mu$-Calpain is highly sensitive to $\mathrm{Ca}^{2+}$ with a half-activation concentration in the range of 3-50 $\mu \mathrm{M}[114,115]$. The enzyme isolated from human RBCs displayed a value of $40 \mu \mathrm{M}$ [54]. This is well above the free $\mathrm{Ca}^{2+}$ concentration 
found in both human RBCs from healthy individuals (30-60 nM) and values of 100-300 nM reported in RBCs from patients with hereditary forms of anaemia [4]. However, a $40 \mathrm{kDa}$ activator protein which makes $\mu$-calpain more $\mathrm{Ca}^{2+}$ sensitive, shifts $\mathrm{Ca}^{2+}$ concentrations required for half-maximal activation from $40-50 \mu \mathrm{M}$ down to $0.2 \mu \mathrm{M}$ [55]. In human RBCs a fraction of membrane-associated active $\mu$-calpain was detected [116,117]. Activation mediated recruitment of calpain to the membrane [118] was used to estimate the protease activity revealing that $\sim 7 \%$ of the calpain pool is constitutively active in RBCs from healthy individuals [117]. Consequently, the $\mu$-calpain activity in RBCs from patients with hereditary anaemia forms was also increased because their resting $\mathrm{Ca}^{2+}$ levels were raised when compared to those from healthy donors. [4].

Targets of activated calpain are mainly transmembrane or membrane-associated proteins including PMCA, and bands 1, 2, 2.1, 3, 4.1, 4.2 proteins, but also calpain itself [119]. Autolysis occurs at $\mathrm{Ca}^{2+}$ levels beyond physiological concentrations, namely in the range 50-150 $\mu \mathrm{M}$ [114]. Limited digestion of haemoglobin $\alpha$ and $\beta$ chains by calpain was also reported [120].

Recently, RBCs of a $\mu$-calpain knock-out (KO) mouse displayed an improved deformability [121]. Furthermore it was demonstrated that ankyrin, band 3, band 4.1R, adducin and dematin were degraded in the $\mathrm{Ca}^{2+}$ loaded normal RBCs but not in the KO RBCs [121].

Cleavage of the PMCA by $\mu$-calpain was associated with an activation of the pump, rapid ATP depletion, inactivation of the pump and gradual loss of the transmembrane $\mathrm{Ca}^{2+}$ gradients [122].

Calpastatin, an endogenous inhibitor of $\mu$-calpain, is a natural regulator of the enzyme activity in RBCs. Both major and minor components of calpastatin, calpastatin $\mathrm{H}$ and $\mathrm{L}$ were detected in human RBCs [54]. Interaction of calpastatin with calpain is also $\mathrm{Ca}^{2+}$ sensitive. Half-maximal activation of calpastatin occurs at $40 \mu \mathrm{M} \mathrm{Ca}^{2+}$ [114], in bovine skeletal muscle derived enzyme. Activity of calpain and a decrease in calpastatin levels in RBCs was shown to occur in elderly humans $[123,124]$.

\section{9. $\mathrm{Ca}^{2+}$ and Inter-Cellular Interactions}

Due to the protein activity and lipid remodelling described above one would expect changes in rheological properties of RBC suspensions and indeed in numerous studies provoking increased cytosolic $\mathrm{Ca}^{2+}$ levels, an altered rheology was observed [125-127]. These changes were majorly explained by altered RBC deformability $[128,129]$. However, a second possibility to explain changes in rheological properties of $\mathrm{RBC}$ suspensions is $\mathrm{RBC}$ aggregation.

A participation of $\mathrm{RBC} \mathrm{Ca}{ }^{2+}$ channels in blood clot formation was proposed previously [92,93] following earlier work already suggesting an active participation of RBCs in blood clot formation [130-132]. Further support was given by investigations showing $\mathrm{Ca}^{2+}$ mediated aggregation of RBCs [133-136] and RBC adhesion to the endothelium [137-139]. Further investigations are necessary to specify the required and sufficient conditions for such processes, e.g., the threshold of the intracellular $\mathrm{Ca}^{2+}$ concentration at which aggregation occurs. Additionally the modulations of the aggregation properties under in vivo conditions need to be elucidated. 


\section{The Physiological Role of Intracellular $\mathrm{Ca}^{2+}$ : From RBC Birth to Clearance}

\section{1. $\mathrm{Ca}^{2+}$ in RBC Haematopoiesis}

$\mathrm{Ca}^{2+}$ uptake is of key importance for promoting differentiation and proliferation of erythroid precursors at the stages of burst-forming units erythroid (BFU-E) colony-forming units erythroid (CFU-E) [140,141]. Increase in the intracellular $\mathrm{Ca}^{2+}$ is an integral part of the signalling pathway activated by binding of erythropoietin to its receptor [142,143]. In $\mathrm{Ca}^{2+}$-free medium, $\mathrm{Ca}^{2+}$ uptake is absent and differentiation and survival of erythroid precursors is compromised [140,141]. Inhibition of $\mathrm{Ca}^{2+}$ uptake by erythroid precursor cells cultured from mononuclear cells by the NMDA receptor antagonist MK-801 resulted in $45.5 \% \pm 12.8 \%$ mortality of cells at the stage of basophilic and polychromatic erythroblasts suggesting that these receptors are actively contributing to erythropoiesis [33]. Additional evidence indicating that $\mathrm{Ca}^{2+}$ levels in reticulocytes are higher than in mature RBCs comes from secondary $\mathrm{Ca}^{2+}$-dependent processes such as phosphorylation [144]. Protein 4.1R phosphorylation by PKC appeared to be markedly elevated in reticulocytes resulting in weakened interaction between $\beta$-spectrin and actin [145].

\section{2. $\mathrm{Ca}^{2+}$ in Relation to the Physiological Function of RBCs}

For a long time, the physiological function of $\mathrm{Ca}^{2+}$ in mature RBCs was obscure and was believed to be limited to the involvement in RBCs aging and clearance [10,146,147]. However, a prominent part of this report reviews the physiological functions of $\mathrm{Ca}^{2+}$ in $\mathrm{RBC}$ regulating a broad range of processes including $\mathrm{O}_{2}$ transport [33], rheology [148], clotting [135,136] and half-life of cells (see Section 4.3). Each of these functions is vital for the organism. Thus, aberrant $\mathrm{Ca}^{2+}$ homeostasis in RBCs results in development of severe life-threatening systemic pathologies.

Very recently, additional evidence in favour of a physiologically important $\mathrm{Ca}^{2+}$ associated mechanism was reported. Here, rises in the intracellular $\mathrm{Ca}^{2+}$ appear to promote the ability of RBCs to deliver oxygen [33].

\section{3. $\mathrm{Ca}^{2+}$ in $\mathrm{RBC}$ Clearance}

At present it is suggested that in senescent RBCs the intracellular $\mathrm{Ca}^{2+}$ levels exceed those in reticulocytes and young RBCs [149]. However, such conclusions on the relationship between cell age and steady-state $\mathrm{Ca}^{2+}$ levels largely depend on the age markers employed. Typical age markers include glycosylated haemoglobin HbA1c, band 4.1a/b ratio, cell density, de-sialation and changes in CD47 abundance at the membrane surface, PS exposure, and several others [149-151].

Activity of the PMCA in RBCs was shown to decrease with progressing HbA1c accumulation [152]. However, based on the pump-leak theory, this process will result in $\mathrm{Ca}^{2+}$ accumulation only when coupled to the unchanged or increasing activity in $\mathrm{Ca}^{2+}$-transporting ion channels. However, according to recent findings, this is not necessarily the case. Young rat and human RBCs contain higher number of NMDA receptors, that upon stimulation with plasma glycine and glutamate can cause significant $\mathrm{Ca}^{2+}$ influx [32,33]. Young cells are preferentially removed in subjects with induced or chronic polycytemia, phenomenon known as neocytolysis [112,153-155]. Finally, 
phosphatydylserine (PS) exposure does not always correlate with high $\mathrm{Ca}^{2+}$ levels [156]. Thus, both young and senescent RBCs appear to be prone to $\mathrm{Ca}^{2+}$ overload, which may well trigger $\mathrm{RBC}$ clearance, but the relation of this mechanism to other $\mathrm{Ca}^{2+}$ independent clearance mechanisms and to in vivo relevance is still obscure.

\section{5. $\mathrm{Ca}^{2+}$ Dysbalance and Haemolytic Anaemia}

Independent of its origin, hereditary haemolytic anaemia is often associated with an increase in the intracellular $\mathrm{Ca}^{2+}$ levels [4]. "Leakiness" of $\mathrm{RBC}$ plasma membrane for $\mathrm{Ca}^{2+}$ that could not be compensated for by the activation of PMCA was reported for patients with SCD [157-159], beta-thalassemia (although most of the $\mathrm{Ca}^{2+}$ seem to be sequestered in vesicles or bound to cytosolic proteins) [160-162], phosphofructokinase deficiency [163]. Most of the information on $\mathrm{Ca}^{2+}$ transport in diseased RBCs was so far obtained for SCD patients. In these cells relatively high rates of $\mathrm{Ca}^{2+}$ uptake in RBCs are partially compensated for by sequestration of $\mathrm{Ca}^{2+}$ into intracellular inside-out vesicles, in which $\mathrm{Ca}^{2+}$ is pumped actively by PMCA [164]. Apparently, this process also exists in RBCs of patients with $\beta$-thalalssemia intermedia $[162,165]$. Furthermore, part of $\mathrm{Ca}^{2+}$ taken into the cells is immobilised by the intracellular proteins. Sickle cell transformation associated with polymerisation of deoxygenated mutated $S$-haemoglobin is amplified by $20-40$-fold by dehydration [166]. Deoxygenation promotes $\mathrm{Ca}^{2+}$ uptake and release of ionised $\mathrm{Ca}^{2+}$ from the intracellular proteins (reduction in buffering capacity) [104,105,167]. In deoxygenated SCD RBC, an acute increase in the intracellular free $\mathrm{Ca}^{2+}$ RBCs causes opening of the $\mathrm{Ca}^{2+}$ sensitive Gardos channel and anion channels [168-170].

Downstream events triggered by augmentation of free intracellular $\mathrm{Ca}^{2+}$ comprise activation of $\mu$-calpain [171] and activation of tyrosine phosphorylation [172]. In RBCs from SCD patients, protein $4.1 \mathrm{R}$ and p55 appear to be phosphorylated thus contributing to the weakened interaction with beta-spectrin [84].

Cross-linked polymers have been observed in RBCs of patients with SCD suggesting hyperactivation of transglutaminase [85].

Oxidation of membrane proteins and impaired NO production by eNOS [173,174], increase in intercellular and RBC-endothelial adhesion [175] are hallmarks of SCD. Cross-linking of the nature of carrier of sickle cell conductance $\left(P_{\text {sickle }}\right)$ mediating $\mathrm{Ca}^{2+}$ uptake by $\mathrm{RBCs}$ remains unknown (compare Section 2.2).

\section{6. $\mathrm{RBC} \mathrm{Ca}{ }^{2+}$ Content and Medicinal Side Effects}

\subsection{Transfusion Medicine}

$\mathrm{Ca}^{2+}$ overload is involved in dramatic reduction of the life span of stored RBCs used for transfusion [176]. Storage of leuco-depleted RBC concentrates is currently performed in $\mathrm{Ca}^{2+}$ free glucose-containing preservation citrate buffers at low temperatures. These storage conditions favour $\mathrm{Ca}^{2+}$ depletion of the cytosol, oxidative stress and ATP deprivation [177,178]. These processes induce deactivation of PMCA, facilitate passive $\mathrm{Ca}^{2+}$ transport and evoke acute $\mathrm{Ca}^{2+}$ overload when re-exposed to the plasma of patients receiving transfusions. The resulting processes include 
dehydration, rigidity, fragmentation of cytoskeletal proteins and oxidative stress and increased adherence of RBCs to the endothelium and to each other $[179,180]$.

\subsection{Therapeutic Side Effects}

Additionally, unwanted modulations of the $\mathrm{Ca}^{2+}$ entry into $\mathrm{RBC}$ may cause side effects of drugs involved in therapies unrelated to RBCs. An example is photodynamic therapy, where the oxidative stress produced by the photosensitizer leads to the activation of cation channels in the RBC membrane and the consecutive $\mathrm{Ca}^{2+}$ entry triggers the mechanism described above, which is the major cause of an increased formation of blood aggregates as well as haemolysis [181]. Thus, RBC remain to be model cells to develop pharmacological strategies [182] and can even be used in automated safety screens [183].

\section{Conclusion and Perspective}

The role of $\mathrm{Ca}^{2+}$ in RBCs physiology and pathophysiology cannot be overestimated. Many links between $\mathrm{Ca}^{2+}$ and $\mathrm{RBC}$ related diseases still need to be explored [184]. Methodologically single cell based methods will increase in their importance and contribution and complement cell population measurements [185]. This is due to the recent hindsight that intercellular heterogeneity and, in some cases, inhomogeneous distribution of $\mathrm{Ca}^{2+}$ within the cytosol are essential to predict the onset of changes related to the abnormally high $\mathrm{Ca}^{2+}$ levels, which are particularly important in patients with haematological disorders $[42,186]$. However, the properties of $\mathrm{Ca}^{2+}$ binding entities within the cells will need further attention and research. Following the broad variety of $\mathrm{Ca}^{2+}$ mediated processes mentioned here, monitoring the following parameters may be used to indirectly predict abnormally increased intracellular free $\mathrm{Ca}^{2+}$ levels in RBCs: (i) changes in cell volume and morphology (microcytosis, high MCHC, increase in cell density, echinocytosis or stomatocytosis); (ii) congenital haemolytic anaemia associated with stomatocytosis, reticulocytosis, and shortened RBC survival; (iii) decrease in the intracellular $\mathrm{K}^{+}$levels, pseudohyperkalemia; (iv) loss of RBC deformability, changes in osmotic resistance, an increase when dehydration has occurred but cytoskeletal stability is still maintained, or a decrease when cytoskeleton is partially disassembled; (v) appearance of calpain-induced band 3 cleavage fragments; (vi) oxidative stress or unusually high NO production (nitrosated $\mathrm{Hb}$, met-Hb); (vii) ATP depletion due to hyperactivation of PMCA; (viii) increase in inter-RBC aggregability; and (ix) increase in PS exposure.

For many years the RBC was the cell of choice for membrane transport investigations. In the age of genomics, interest in $\mathrm{RBC}$ research decreased, but numerous signalling cascades - also in respect to the second messenger $\mathrm{Ca}^{2+}$ that occur in other cells and may involve several organelles- have been rediscovered in a modified and/or simplified form in RBCs.

\section{Conflict of Interest}

The authors declare no conflict of interest. 


\section{References}

1. Berridge, M.J.; Lipp, P.; Bootman, M.D. The versatility and universality of calcium signalling. Nat. Rev. Mol. Cell Biol. 2000, 1, 11-21.

2. Bootman, M.D.; Berridge, M.J.; Lipp, P. Cooking with calcium: The recipes for composing global signals from elementary events. Cell 1997, 91, 367-373.

3. Bookchin, R.M.; Lew, V.L. Progressive inhibition of the Ca pump and Ca:Ca exchange in sickle red cells. Nature 1980, 284, 561-563.

4. Tiffert, T.; Bookchin, R.M.; Lew, V.L. Calcium Homeostasis in Normal and Abnormal Human Red Cells. In Red Cell Membrane Transport in Health and Disease; Bernhardt, I., Ellory, C., Eds.; Springer Verlag: Heidelberg, Germany, 2003; pp. 373-405.

5. Wilbrandt, W. A relation between the permeability of the red cell and its metabolism. Trans. Faraday Soc. 1937, 33, 956-959.

6. Pasini, E.M.; Kirkegaard, M.; Mortensen, P.; Lutz, H.U.; Thomas, A.W.; Mann, M. In-depth analysis of the membrane and cytosolic proteome of red blood cells. Blood 2006, 108, 791-801.

7. Strehler, E.E.; Caride, A.J.; Filoteo, A.G.; Xiong, Y.; Penniston, J.T.; Enyedi, A. Plasma membrane $\mathrm{Ca}^{2+}$ ATPases as dynamic regulators of cellular calcium handling. Ann. N. Y. Acad. Sci. 2007, 1099, 226-236.

8. Tiffert, T.; Lew, V.L. Elevated intracellular $\mathrm{Ca}^{2+}$ reveals a functional membrane nucleotide pool in intact human red blood cells. J. Gen. Physiol. 2011, 138, 381-391.

9. Romero, P.J.; Romero, E.A. Differences in $\mathrm{Ca}^{2+}$ pumping activity between sub-populations of human red cells. Cell Calcium 1997, 21, 353-358.

10. Romero, P.J.; Romero, E.A. The role of calcium metabolism in human red blood cell ageing: A proposal. Blood Cells Mol. Dis. 1999, 25, 9-19.

11. Schatzmann, H.J. Dependence on calcium concentration and stoichiometry of the calcium pump in human red cells. J. Physiol. 1973, 235, 551-569.

12. Chu, H.; Puchulu-Campanella, E.; Galan, J.A.; Taob, W.A.; Low, P.S.; Hoffman, J.F. Identification of cytoskeletal elements enclosing the ATP pools that fuel human red blood cell membrane cation pumps. Proc. Natl. Acad. Sci. USA 2012, 109, 12794-12799.

13. Hoffman, J.F.; Dodson, A.; Proverbio, F. On the functional use of the membrane compartmentalized pool of ATP by the $\mathrm{Na}^{+}$and $\mathrm{Ca}^{++}$pumps in human red blood cell ghosts. J. Gen. Physiol. 2009, 134, 351-361.

14. Garrahan, P.J.; Rega, A.F. Activation of partial reactions of the $\mathrm{Ca}^{2+}$-ATPase from human red cells by $\mathrm{Mg}^{2+}$ and ATP. Biochim. Biophys. Acta 1978, 513, 59-65.

15. Bredeston, L.M.; Rega, A.F. Phosphatidylcholine makes specific activity of the purified $\mathrm{Ca}^{2+}$-ATPase from plasma membranes independent of enzyme concentration. Biochim. Biophys. Acta 1999, 1420, 57-62.

16. Colina, C.; Cervino, V.; Benaim, G. Ceramide and sphingosine have an antagonistic effect on the plasma-membrane $\mathrm{Ca}^{2+}$-ATPase from human erythrocytes. Biochem. J. 2002, 362, 247-251.

17. Oliveira, V.H.; Nascimento, K.S.O.; Freire, M.M.; Moreira, O.C.; Scofano, H.M.; Barrabin, H.; Mignaco, J.A. Mechanism of modulation of the plasma membrane $\mathrm{Ca}^{2+}$-ATPase by arachidonic acid. Prostaglandins Other Lipid Mediat. 2008, 87, 47-53. 
18. Sarkadi, B.; Szasz, I.; Gerloczy, A.; Gardos, G. Transport parameters and stoichiometry of active calcium-ion extrusion in intact human red-cells. Biochim. Biophys. Acta 1977, 464, 93-107.

19. Kaestner, L. Cation channels in erythrocytes-Historical and future perspective. Open Biol. J. 2011, 4, 27-34.

20. Christophersen, P.; Bennekou, P. Evidence for a voltage-gated, non-selective cation channel in the human red cell membrane. Biochim. Biophys. Acta 1991, 1065, 103-106.

21. Bennekou, P. The voltage-gated non-selective cation channel from human red cells is sensitive to acetylcholine. Biochim. Biophys. Acta 1993, 1147, 165-167.

22. Kaestner, L.; Bollensdorff, C.; Bernhardt, I. Non-selective voltage-activated cation channel in the human red blood cell membrane. Biochim. Biophys. Acta 1999, 1417, 9-15.

23. Kaestner, L.; Christophersen, P.; Bernhardt, I.; Bennekou, P. The non-selective voltage-activated cation channel in the human red blood cell membrane: Reconciliation between two conflicting reports and further characterisation. Bioelectrochemistry 2000, 52, 117-125.

24. Rodighiero, S.; de Simoni, A.; Formenti, A. The voltage-dependent nonselective cation current in human red blood cells studied by means of whole-cell and nystatin-perforated patch-clamp techniques. Biochim. Biophys. Acta 2004, 1660, 164-170.

25. Bennekou, P.; Kristensen, B.I.; Christophersen, P. The human red cell voltage-regulated cation channel. The interplay with the chloride conductance, the $\mathrm{Ca}^{2+}$-activated $\mathrm{K}^{+}$channel and the $\mathrm{Ca}^{2+}$ pump. J. Membr. Biol. 2003, 195, 1-8.

26. Bennekou, P.; Barksmann, T.L.; Kristensen, B.I.; Jensen, L.R.; Christophersen, P. Pharmacology of the human red cell voltage-dependent cation channel. Part II: Inactivation and blocking. Blood Cells Mol. Dis. 2004, 33, 356-361.

27. Bennekou, P.; Barksmann, T.L.; Christophersen, P.; Kristensen, B.I. The human red cell voltage-dependent cation channel. Part III: Distribution homogeneity and $\mathrm{pH}$ dependence. Blood Cells Mol. Dis. 2006, 36, 10-14.

28. Yang, L.; Andrews, D.A.; Low, P.S. Lysophosphatidic acid opens a $\mathrm{Ca}^{++}$channel in human erythrocytes. Blood 2000, 95, 2420-2425.

29. Andrews, D.A.; Yang, L.; Low, P.S. Phorbol ester stimulates a protein kinase $C$-mediated agatoxin-TK-sensitive calcium permeability pathway in human red blood cells. Blood 2002, 100, 3392-3399.

30. Wagner-Britz, L.; Wang, J.; Kaestner, L.; Bernhardt, I. Protein Kinase C $\alpha$ and P-Type $\mathrm{Ca}^{2+}$-Channel CaV2.1 in Red Blood Cells cCalcium Signaling. J. Cell. Physiol. Biochem. 2013, in revision.

31. Foller, M.; Kasinathan, R.S.; Koka, S.; Lang, C.; Shumilina, E.V.; Birnbaumer, L.; Lang, F.; Huber, S.M. TRPC6 contributes to the $\mathrm{Ca}^{2+}$ leak of human erythrocytes. Cell Physiol. Biochem. 2008, 21, 183-192.

32. Makhro, A.; Wang, J.; Vogel, J.; Boldyrev, A.A.; Gassmann, M.; Kaestner, L.; Bogdanova, A.Y. Functional NMDA receptors in rat erythrocytes. Am. J. Physiol. Cell Physiol. 2010, 298, C1315-C1325.

33. Makhro, A.; Hanggi, P.; Goede, J.; Wang, J.; Brüggemann, A.; Gassmann, M.; Kaestner, L.; Speer, O.; Bogdanova, A. N-Methyl D-Aspartate (NMDA) Receptors in Erythroid Precursor Cells and in Circulating Human Red Blood Cells Contributes to the Regulation of Intracellular Calcium Levels. Am. J. Physiol. 2013, in revision. 
34. Madry, C.; Betz, H.; Geiger, J.R.P.; Laube, B. Supralinear potentiation of NR1/NR3A excitatory glycine receptors by $\mathrm{Zn}^{2+}$ and NR1 antagonist. Proc. Natl. Acad. Sci. USA 2008, 105, 12563-12568.

35. Zarychanski, R.; Schulz, V.P.; Houston, B.L.; Maksimova, Y.; Houston, D.S.; Smith, B.; Rinehart, J.; Gallagher, P.G. Mutations in the mechanotransduction protein PIEZO1 are associated with hereditary xerocytosis. Blood 2012, 120, 1908-1915.

36. Gottlieb, P.A.; Sachs, F. Piezo1: Properties of a cation selective mechanical channel. Channels (Austin) 2012, 6, 214-219.

37. Gottlieb, P.A.; Bae, C.; Sachs, F. Gating the mechanical channel Piezo1: A comparison between whole-cell and patch recording. Channels (Austin) 2012, 6, 282-289.

38. Foller, M.; Mahmud, H.; Gu, S.; Kucherenko, Y.; Gehring, E.-M.; Shumilina, E.; Floride, E.; Sprengel, R.; Lang, F. Modulation of suicidal erythrocyte cation channels by an AMPA antagonist. J. Cell. Mol. Med. 2009, 13, 3680-3686.

39. Browning, J.A.; Staines, H.M.; Robinson, H.C.; Powell, T.; Ellory, J.C.; Gibson, J.S. The effect of deoxygenation on whole-cell conductance of red blood cells from healthy individuals and patients with sickle cell disease. Blood 2007, 109, 2622-2629.

40. Ma, Y.-L.; Rees, D.C.; Gibson, J.S.; Ellory, J.C. The conductance of red blood cells from sickle cell patients: Ion selectivity and inhibitors. J. Physiol. (Lond.) 2012, 590, 2095-2105.

41. Lew, V.L.; Ortiz, O.E.; Bookchin, R.M. Stochastic nature and red cell population distribution of the sickling-induced $\mathrm{Ca}^{2+}$ permeability. J. Clin. Invest. 1997, 99, 2727-2735.

42. Bogdanova, A.; Makhro, A.; Wang, J.; Gassmann, M.; Kaestner, L. Responses of rat erythrocytes to homocysteine and homocysteic acid treatment. Clin. Biochem. 2009, 42, 1858-1859.

43. Clapham, D.E. Calcium signaling. Cell 2007, 131, 1047-1058.

44. Meador, W.E.; Means, A.R.; Quiocho, F.A. Target enzyme recognition by calmodulin: 2.4 A structure of a calmodulin-peptide complex. Science 1992, 257, 1251-1255.

45. Meador, W.E.; Means, A.R.; Quiocho, F.A. Modulation of calmodulin plasticity in molecular recognition on the basis of X-ray structures. Science 1993, 262, 1718-1721.

46. Cho, W.; Stahelin, R.V. Membrane-protein interactions in cell signaling and membrane trafficking. Annu. Rev. Biophys. Biomol. Struct. 2005, 34, 119-151.

47. Thomas, D.; Tovey, S.C.; Collins, T.J.; Bootman, M.D.; Berridge, M.J.; Lipp, P. A comparison of fluorescent $\mathrm{Ca}^{2+}$ indicator properties and their use in measuring elementary and global $\mathrm{Ca}^{2+}$ signals. Cell Calcium 2000, 28, 213-223.

48. Kaestner, L.; Tabellion, W.; Weiss, E.; Bernhardt, I.; Lipp, P. Calcium imaging of individual erythrocytes: Problems and approaches. Cell Calcium 2006, 39, 13-19.

49. Jarrett, H.W.; Kyte, J. Human erythrocyte calmodulin. Further chemical characterization and the site of its interaction with the membrane. J. Biol. Chem. 1979, 254, 8237-8244.

50. Leinders, T.; van Kleef, R.G.; Vijverberg, H.P. Single $\mathrm{Ca}^{2+}$-activated $\mathrm{K}^{+}$channels in human erythrocytes: $\mathrm{Ca}^{2+}$ dependence of opening frequency but not of open lifetimes. Biochim. Biophys. Acta 1992, 1112, 67-74.

51. Stout, J.G.; Zhou, Q.; Wiedmer, T.; Sims, P.J. Change in conformation of plasma membrane phospholipid scramblase induced by occupancy of its $\mathrm{Ca}^{2+}$ binding site. Biochemistry 1998, 37, 14860-14866. 
52. Woon, L.A.; Holland, J.W.; Kable, E.P.; Roufogalis, B.D. $\mathrm{Ca}^{2+}$ sensitivity of phospholipid scrambling in human red cell ghosts. Cell Calcium 1999, 25, 313-320.

53. Bitbol, M.; Fellmann, P.; Zachowski, A.; Devaux, P.F. Ion regulation of phosphatidylserine and phosphatidylethanolamine outside-inside translocation in human erythrocytes. Biochim. Biophys. Acta 1987, 904, 268-282.

54. Murakami, T.; Hatanaka, M.; Murachi, T. The cytosol of human erythrocytes contains a highly $\mathrm{Ca}^{2+}$-sensitive thiol protease (calpain I) and its specific inhibitor protein (calpastatin). J. Biochem 1981, 90, 1809-1816.

55. Salamino, F.; de Tullio, R.; Mengotti, P.; Viotti, P.L.; Melloni, E.; Pontremoli, S. Site-directed activation of calpain is promoted by a membrane-associated natural activator protein. Biochem. J. 1993, 290, 191-197.

56. Bergamini, C.M.; Signorini, M. Studies on tissue transglutaminases: Interaction of erythrocyte type-2 transglutaminase with GTP. Biochem. J. 1993, 291, 37-39.

57. Almaraz, L.; García-Sancho, J.; Lew, V.L. Calcium-induced conversion of adenine nucleotides to inosine monophosphate in human red cells. J. Physiol. (Lond.) 1988, 407, 557-567.

58. Kohout, S.C.; Corbalán-García, S.; Torrecillas, A.; Goméz-Fernandéz, J.C.; Falke, J.J. C2 domains of protein kinase $\mathrm{C}$ isoforms alpha, beta, and gamma: Activation parameters and calcium stoichiometries of the membrane-bound state. Biochemistry 2002, 41, 11411-11424.

59. Kuhlman, P.A.; Hughes, C.A.; Bennett, V.; Fowler, V.M. A new function for adducin. Calcium/calmodulin-regulated capping of the barbed ends of actin filaments. J. Biol. Chem. 1996, 271, 7986-7991.

60. Kifor, G.; Toon, M.R.; Janoshazi, A.; Solomon, A.K. Interaction between red cell membrane band 3 and cytosolic carbonic anhydrase. J. Membr. Biol. 1993, 134, 169-179.

61. Li, X.; Alvarez, B.; Casey, J.R.; Reithmeier, R.A.F.; Fliegel, L. Carbonic anhydrase II binds to and enhances activity of the $\mathrm{Na}^{+} / \mathrm{H}^{+}$exchanger. J. Biol. Chem. 2002, 277, 36085-36091.

62. Nunomura, W.; Denker, S.P.; Barber, D.L.; Takakuwa, Y.; Gascard, P. Characterization of cytoskeletal protein $4.1 \mathrm{R}$ interaction with NHE1 $\left(\mathrm{Na}^{+} / \mathrm{H}^{+}\right.$exchanger isoform 1). Biochem. J. 2012, 446, 427-435.

63. An, X.; Zhang, X.; Debnath, G.; Baines, A.J.; Mohandas, N. Phosphatidylinositol-4,5biphosphate (PIP2) differentially regulates the interaction of human erythrocyte protein 4.1 (4.1R) with membrane proteins. Biochemistry 2006, 45, 5725-5732.

64. Nunomura, W.; Sasakura, D.; Shiba, K.; Nakamura, S.; Kidokoro, S.-I.; Takakuwa, Y. Structural stabilization of protein 4.1R FERM domain upon binding to apo-calmodulin: Novel insights into the biological significance of the calcium-independent binding of calmodulin to protein 4.1R. Biochem. J. 2011, 440, 367-374.

65. Lipp, P.; Reither, G. Protein kinase C: The "masters" of calcium and lipid. Cold Spring Harb. Perspect. Biol. 2011, 3, doi:10.1101/cshperspect.a004556.

66. Govekar, R.B.; Zingde, S.M. Protein kinase C isoforms in human erythrocytes. Ann. Hematol. 2001, 80, 531-534.

67. Newton, A.C. Protein kinase C: Structural and spatial regulation by phosphorylation, cofactors, and macromolecular interactions. Chem. Rev. 2001, 101, 2353-2364. 
68. Steinberg, S.F. Structural basis of protein kinase C isoform function. Physiol. Rev. 2008, 88, 1341-1378.

69. Wright, L.C.; Chen, S.; Roufogalis, B.D. Regulation of the activity and phosphorylation of the plasma membrane $\mathrm{Ca}^{2+}$-ATPase by protein kinase $\mathrm{C}$ in intact human erythrocytes. Arch. Biochem. Biophys. 1993, 306, 277-284.

70. Cohen, C.M.; Gascard, P. Regulation and post-translational modification of erythrocyte membrane and membrane-skeletal proteins. Semin. Hematol. 1992, 29, 244-292.

71. De Oliveira, S.; Silva-Herdade, A.S.; Saldanha, C. Modulation of erythrocyte deformability by PKC activity. Clin. Hemorheol. Microcirc. 2008, 39, 363-373.

72. George, A.; Pushkaran, S.; Konstantinidis, D.G.; Koochaki, S.; Malik, P.; Mohandas, N.; Zheng, Y.; Joiner, C.H.; Kalfa, T.A. Erythrocyte NADPH oxidase activity modulated by Rac GTPases, PKC, and plasma cytokines contributes to oxidative stress in sickle cell disease. Blood 2013, 121, 2099-2107.

73. Ceolotto, G.; Conlin, P.; Clari, G.; Semplicini, A.; Canessa, M. Protein kinase C and insulin regulation of red blood cell Na ${ }^{+} / \mathrm{H}^{+}$exchange. Am. J. Physiol. 1997, 272, C818-C826.

74. Mohandas, N.; Gallagher, P.G. Red cell membrane: Past, present, and future. Blood 2008, 112, 3939-3948.

75. Bruce, L.J.; Beckmann, R.; Ribeiro, M.L.; Peters, L.L.; Chasis, J.A.; Delaunay, J.; Mohandas, N.; Anstee, D.J.; Tanner, M.J.A. A band 3-based macrocomplex of integral and peripheral proteins in the RBC membrane. Blood 2003, 101, 4180-4188.

76. Salomao, M.; Zhang, X.; Yang, Y.; Lee, S.; Hartwig, J.H.; Chasis, J.A.; Mohandas, N.; An, X. Protein 4.1R-dependent multiprotein complex: New insights into the structural organization of the red blood cell membrane. Proc. Natl. Acad. Sci. USA 2008, 105, 8026-8031.

77. Rivera, A.; de Franceschi, L.; Peters, L.L.; Gascard, P.; Mohandas, N.; Brugnara, C. Effect of complete protein $4.1 \mathrm{R}$ deficiency on ion transport properties of murine erythrocytes. Am. J. Physiol. Cell Physiol. 2006, 291, C880-C886.

78. Hoeflich, K.P.; Ikura, M. Calmodulin in action: Diversity in target recognition and activation mechanisms. Cell 2002, 108, 739-742.

79. Chin, D.; Means, A.R. Calmodulin: A prototypical calcium sensor. Trends Cell Biol. 2000, 10, 322-328.

80. Vetter, S.W.; Leclerc, E. Phosphorylation of serine residues affects the conformation of the calmodulin binding domain of human protein 4.1. Eur. J. Biochem. FEBS 2001, 268, 4292-4299.

81. Gauthier, E.; Guo, X.; Mohandas, N.; An, X. Phosphorylation-dependent perturbations of the 4.1R-associated multiprotein complex of the erythrocyte membrane. Biochemistry 2011, 50, 4561-4567.

82. Dyrda, A.; Cytlak, U.; Ciuraszkiewicz, A.; Lipinska, A.; Cueff, A.; Bouyer, G.; Egée, S.; Bennekou, P.; Lew, V.L.; Thomas, S.L.Y. Local membrane deformations activate $\mathrm{Ca}^{2+}$-dependent $\mathrm{K}+$ and anionic currents in intact human red blood cells. PLoS One 2010, 5 , e9447.

83. Manno, S.; Takakuwa, Y.; Mohandas, N. Modulation of erythrocyte membrane mechanical function by protein 4.1 phosphorylation. J. Biol. Chem. 2005, 280, 7581-7587. 
84. George, A.; Pushkaran, S.; Li, L.; An, X.; Zheng, Y.; Mohandas, N.; Joiner, C.H.; Kalfa, T.A. Altered phosphorylation of cytoskeleton proteins in sickle red blood cells: The role of protein kinase C, Rac GTPases, and reactive oxygen species. Blood Cells Mol. Dis. 2010, 45, 41-45.

85. Lorand, L.; Murthy, S.N.P.; Khan, A.A.; Xue, W.; Lockridge, O.; Chishti, A.H. Transglutaminase-mediated remodeling of the human erythrocyte membrane skeleton: Relevance for erythrocyte diseases with shortened cell lifespan. Adv. Enzymol. Relat. Areas Mol. Biol. 2011, $78,385-414$.

86. Guizouarn, H.; Gabillat, N.; Motais, R.; Borgese, F. Multiple transport functions of a red blood cell anion exchanger, tAE1: Its role in cell volume regulation. J. Physiol. (Lond.) 2001, 535, 497-506.

87. Gardos, G. The function of calcium in the potassium permeability of human erythrocytes. Biochim. Biophys. Acta 1958, 30, 653-654.

88. Hamill, O.P. Potassium channel currents in human red blood cells. J. Physiol. (Lond.) 1981, 319, 97P-98P.

89. Hamill, O.P. Potassium and Chloride Channels in Red Blood Cells. In Single Channel Recording; Sakmann, B., Neher, E., Eds.; Plenum Press: New York, NY, USA and London, UK, 1983; pp. 451-471.

90. Grygorczyk, R.; Schwarz, W. Properties of the $\mathrm{Ca}^{2+}$-activated $\mathrm{K}^{+}$conductance of human red cells as revealed by the patch-clamp technique. Cell Calcium 1983, 4, 499-510.

91. Hoffman, J.F.; Joiner, W.; Nehrke, K.; Potapova, O.; Foye, K.; Wickrema, A. The hSK4 (KCNN4) isoform is the $\mathrm{Ca}^{2+}$-activated $\mathrm{K}^{+}$channel (Gardos channel) in human red blood cells. Proc. Natl. Acad. Sci. USA 2003, 100, 7366-7371.

92. Kaestner, L.; Bernhardt, I. Ion channels in the human red blood cell membrane: Their further investigation and physiological relevance. Bioelectrochemistry 2002, 55, 71-74.

93. Kaestner, L.; Tabellion, W.; Lipp, P.; Bernhardt, I. Prostaglandin E2 activates channel-mediated calcium entry in human erythrocytes: An indication for a blood clot formation supporting process. Thromb. Haemostasis 2004, 92, 1269-1272.

94. Bassé, F.; Stout, J.G.; Sims, P.J.; Wiedmer, T. Isolation of an erythrocyte membrane protein that mediates $\mathrm{Ca}^{2+}$-dependent transbilayer movement of phospholipid. J. Biol. Chem. 1996, 271, 17205-17210.

95. Verkleij, A.J.; Zwaal, R.F.; Roelofsen, B.; Comfurius, P.; Kastelijn, D.; van Deenen, L.L. The asymmetric distribution of phospholipids in the human red cell membrane. A combined study using phospholipases and freeze-etch electron microscopy. Biochim. Biophys. Acta 1973, 323, 178-193.

96. Zhou, Q.; Zhao, J.; Stout, J.G.; Luhm, R.A.; Wiedmer, T.; Sims, P.J. Molecular cloning of human plasma membrane phospholipid scramblase. A protein mediating transbilayer movement of plasma membrane phospholipids. J. Biol. Chem. 1997, 272, 18240-18244.

97. Morrot, G.; Hervé, P.; Zachowski, A.; Fellmann, P.; Devaux, P.F. Aminophospholipid translocase of human erythrocytes: Phospholipid substrate specificity and effect of cholesterol. Biochemistry 1989, 28, 3456-3462. 
98. Beitner, R. Control of glycolytic enzymes through binding to cell structures and by glucose-1,6-bisphosphate under different conditions. The role of $\mathrm{Ca}^{2+}$ and calmodulin. Int. J. Biochem. 1993, 25, 297-305.

99. Nakashima, K.; Fujii, S.; Kaku, K.; Kaneko, T. Calcium-calmodulin dependent phosphorylation of erythrocyte pyruvate kinase. Biochem. Biophys. Res. Commun. 1982, 104, 285-289.

100. Campanella, M.E.; Chu, H.; Low, P.S. Assembly and regulation of a glycolytic enzyme complex on the human erythrocyte membrane. Proc. Natl. Acad. Sci. USA 2005, 102, 2402-2407.

101. Zipser, Y.; Piade, A.; Barbul, A.; Korenstein, R.; Kosower, N.S. Ca ${ }^{2+}$ promotes erythrocyte band 3 tyrosine phosphorylation via dissociation of phosphotyrosine phosphatase from band 3 . Biochem. J. 2002, 368, 137-144.

102. Chu, H.; Low, P.S. Mapping of glycolytic enzyme-binding sites on human erythrocyte band 3. Biochem. J. 2006, 400, 143-151.

103. Chu, H.; Breite, A.; Ciraolo, P.; Franco, R.S.; Low, P.S. Characterization of the deoxyhemoglobin binding site on human erythrocyte band 3: Implications for $\mathrm{O}_{2}$ regulation of erythrocyte properties. Blood 2008, 111, 932-938.

104. Tiffert, T.; Etzion, Z.; Bookchin, R.M.; Lew, V.L. Effects of deoxygenation on active and passive $\mathrm{Ca}^{2+}$ transport and cytoplasmic $\mathrm{Ca}^{2+}$ buffering in normal human red cells. J. Physiol. (Lond.) 1993, 464, 529-544.

105. Tiffert, T.; Lew, V.L. Cytoplasmic calcium buffers in intact humanred cells. J. Physiol. (Lond.) 1997, 500, 139-154.

106. Alderton, W.K.; Cooper, C.E.; Knowles, R.G. Nitric oxide synthases: Structure, function and inhibition. Biochem. J. 2001, 357, 593-615.

107. Spratt, D.E.; Newman, E.; Mosher, J.; Ghosh, D.K.; Salerno, J.C.; Guillemette, J.G. Binding and activation of nitric oxide synthase isozymes by calmodulin EF hand pairs. FEBS J. 2006, 273, $1759-1771$.

108. Kleinbongard, P.; Schulz, R.; Rassaf, T.; Lauer, T.; Dejam, A.; Jax, T.; Kumara, I.; Gharini, P.; Kabanova, S.; Ozüyaman, B.; et al. Red blood cells express a functional endothelial nitric oxide synthase. Blood 2006, 107, 2943-2951.

109. Ozüyaman, B.; Grau, M.; Kelm, M.; Merx, M.W.; Kleinbongard, P. RBC NOS: Regulatory mechanisms and therapeutic aspects. Trends Mol. Med. 2008, 14, 314-322.

110. Ulker, P.; Yaras, N.; Yalcin, O.; Celik-Ozenci, C.; Johnson, P.C.; Meiselman, H.J.; Baskurt, O.K. Shear stress activation of nitric oxide synthase and increased nitric oxide levels in human red blood cells. Nitric Oxide 2011, 24, 184-191.

111. Cave, A.C.; Brewer, A.C.; Narayanapanicker, A.; Ray, R.; Grieve, D.J.; Walker, S.; Shah, A.M. NADPH oxidases in cardiovascular health and disease. Antioxid. Redox Signal. 2006, 8, 691-728.

112. Mihov, D.; Vogel, J.; Gassmann, M.; Bogdanova, A.Y. Erythropoietin activates nitric oxide synthase in murine erythrocytes. Am. J. Physiol. Cell Physiol. 2009, 297, C378-C388.

113. Inomata, M.; Nakamura, M., Imajoh-Ohmi, S.; Kawashima, S. A variety of calpain/calpastatin systems in mammalian erythrocytes. Biochim. Biophys. Acta 1993, 1178, 207-214.

114. Goll, D.E.; Thompson, V.F.; Li, H.; Wei, W.; Cong, J. The calpain system. Physiol. Rev. 2003, $83,731-801$. 
115. Campbell, R.L.; Davies, P.L. Structure-function relationships in calpains. Biochem. J. 2012, 447, $335-351$.

116. Hatanaka, M.; Yoshimura, N.; Murakami, T.; Kannagi, R.; Murachi, T. Evidence for membrane-associated calpain I in human erythrocytes. Detection by an immunoelectrophoretic blotting method using monospecific antibody. Biochemistry 1984, 23, 3272-3276.

117. Samis, J.A.; Elce, J.S. Immunogold electron-microscopic localization of calpain I in human erythrocytes. Thromb. Haemost. 1989, 61, 250-253.

118. Molinari, M.; Anagli, J.; Carafoli, E. $\mathrm{Ca}^{2+}$-activated neutral protease is active in the erythrocyte membrane in its nonautolyzed 80-kDa form. J. Biol. Chem. 1994, 269, 27992-27995.

119. Mortensen, A.M.; Novak, R.F. Dynamic changes in the distribution of the calcium-activated neutral protease in human red blood cells following cellular insult and altered $\mathrm{Ca}^{2+}$ homeostasis. Toxicol. Appl. Pharmacol. 1992, 117, 180-188.

120. Melloni, E.; Salamino, F.; Sparatore, B.; Michetti, M.; Pontremoli, S. Ca2+-dependent neutral proteinase from human erythrocytes: Activation by $\mathrm{Ca}^{2+}$ ions and substrate and regulation by the endogenous inhibitor. Biochem. Int. 1984, 8, 477-489.

121. Wieschhaus, A.; Khan, A.; Zaidi, A.; Rogalin, H.; Hanada, T.; Liu, F.; de Franceschi, L.; Brugnara, C.; Rivera, A.; Chishti, A.H. Calpain-1 knockout reveals broad effects on erythrocyte deformability and physiology. Biochem. J. 2012, 448, 141-152.

122. Molinari, M.; Maki, M.; Carafoli, E. Purification of mu-calpain by a novel affinity chromatography approach. New insights into the mechanism of the interaction of the protease with targets. J. Biol. Chem. 1995, 270, 14576-14581.

123. Schwarz-Benmeir, N.; Glaser, T.; Barnoy, S.; Kosower, N.S. Calpastatin in erythrocytes of young and old individuals. Biochem. J. 1994, 304, 365-370.

124. Glaser, T.; Schwarz-Benmeir, N.; Barnoy, S.; Barak, S.; Eshhar, Z.; Kosower, N.S. Calpain $\left(\mathrm{Ca}^{2+}\right.$-dependent thiol protease) in erythrocytes of young and old individuals. Proc. Natl. Acad. Sci. USA 1994, 91, 7879-7883.

125. Rademaker, M.; Thomas, R.H.; Kirby, J.D.; Kovacs, I.B. Calcium influx into red blood cells: The effect of sera from patients with systemic sclerosis. Clin. Exp. Rheumatol. 1991, 9, 247-251.

126. Hung, T.C.; Pham, S.; Steed, D.L.; Webster, M.W.; Butter, D.B. Alterations in erythrocyte rheology in patients with severe peripheral vascular disease: 1. Cell volume dependence of erythrocyte rigidity. Angiology 1991, 42, 210-217.

127. Jendryczko, A.; Pardela, M. Abnormal effect of sera from patients with atherosclerosis on calcium influx into normal erythrocytes. Cor. Vasa 1992, 34, 428-433.

128. Piagnerelli, M.; Boudjeltia, K.Z.; Vanhaeverbeek, M.; Vincent, J.-L. Red blood cell rheology in sepsis. Intensive Care Med. 2003, 29, 1052-1061.

129. Baskurt, O.; Neu, B.; Meiselman, H.J. Red Blood Cell Aggregation; CRC Press: Boca Raton, FL, USA, 2012.

130. Duke, W.W. The relation of blood platelets to hemorrhagic disease. Description of a method for determining the bleeding time and coagulation time and report of three cases of hemorrhagic disease relieved by transfusion. J. Am. Med. Assoc. 1910, 55, 1185-1192.

131. Hellem, A.J.; Borchgrevink, C.F.; Ames, S.B. The role of red cells in haemostasis: The relation between haematocrit, bleeding time and platelet adhesiveness. Br. J. Haematol. 1961, 7, 42-50. 
132. Andrews, D.A.; Low, P.S. Role of red blood cells in thrombosis. Curr. Opin. Hematol. 1999, 6, 76-82.

133. Chung, S.M.; Bae, O.N.; Lim, K.M.; Noh, J.Y.; Lee, M.Y.; Jung, Y.S.; Chung, J.H. Lysophosphatidic acid induces thrombogenic activity through phosphatidylserine exposure and procoagulant microvesicle generation in human erythrocytes. Arterioscl. Thromb. Vasc. Biol. 2007, 27, 414-421.

134. Noh, J.-Y.; Lim, K.-M.; Bae, O.-N.; Chung, S.-M.; Lee, S.-W.; Joo, K.-M.; Lee, S.-D.; Chung, J.-H. Procoagulant and prothrombotic activation of human erythrocytes by phosphatidic acid. AJP Heart Circ. Physiol. 2010, 299, H347-H355.

135. Steffen, P.; Jung, A.; Nguyen, D.B.; Müller, T.; Bernhardt, I.; Kaestner, L.; Wagner, C. Stimulation of human red blood cells leads to $\mathrm{Ca}^{2+}$-mediated intercellular adhesion. Cell Calcium 2011, 50, 54-61.

136. Kaestner, L.; Steffen, P.; Nguyen, D.B.; Wang, J.; Wagner-Britz, L.; Jung, A.; Wagner, C.; Bernhardt, I. Lysophosphatidic acid induced red blood cell aggregation in vitro. Bioelectrochemistry 2012, 87, 89-95.

137. Wautier, M.-P.; Nemer, El, W.; Gane, P.; Rain, J.-D.; Cartron, J.-P.; Colin, Y.; le van Kim, C.; Wautier, J.-L. Increased adhesion to endothelial cells of erythrocytes from patients with polycythemia vera is mediated by laminin alpha5 chain and Lu/BCAM. Blood 2007, 110, 894-901.

138. Yedgar, S.; Kaul, D.K.; Barshtein, G. RBC adhesion to vascular endothelial cells: More potent than RBC aggregation in inducing circulatory disorders. Microcirculation 2008, 15, 581-583.

139. Wautier, M.-P.; Héron, E.; Picot, J.; Colin, Y.; Hermine, O.; Wautier, J.-L. Red blood cell phosphatidylserine exposure is responsible for increased erythrocyte adhesion to endothelium in central retinal vein occlusion. J. Thromb. Haemost. 2011, 9, 1049-1055.

140. Miller, B.A.; Cheung, J.Y. Mechanisms of erythropoietin signal transduction: Involvement of calcium channels. Proc. Soc. Exp. Biol. Med. 1994, 206, 263-267.

141. Schaefer, A.; Magócsi, M.; Marquardt, H. Signalling mechanisms in erythropoiesis: The enigmatic role of calcium. Cell. Signal. 1997, 9, 483-495.

142. Cheung, J.Y.; Zhang, X.Q.; Bokvist, K.; Tillotson, D.L.; Miller, B.A. Modulation of calcium channels in human erythroblasts by erythropoietin. Blood 1997, 89, 92-100.

143. Miller, B.A.; Cheung, J.Y.; Tillotson, D.L.; Hope, S.M.; Scaduto, R.C. Erythropoietin stimulates a rise in intracellular-free calcium concentration in single BFU-E derived erythroblasts at specific stages of differentiation. Blood 1989, 73, 1188-1194.

144. De Haro, C.; de Herreros, A.G.; Ochoa, S. Protein phosphorylation and translational control in reticulocytes: Activation of the heme-controlled translational inhibitor by calcium ions and phospholipid. Curr. Top. Cell. Regul. 1985, 27, 63-81.

145. Liu, J.; Guo, X.; Mohandas, N.; Chasis, J.A.; An, X. Membrane remodeling during reticulocyte maturation. Blood 2010, 115, 2021-2027.

146. Bookchin, R.M.; Lew, V.L.; Roth, E.F. Elevated Red Cell Calcium: Innocent Bystander or Kiss of Death? In Cellular and Molecular Aspects of Aging: The Red Cell as a Model; Eaton, J.W., Ed.; John Wiley \& Sons: New York, NY, USA, 1985; pp. 369-375. 
147. Clark, M.R. Senescence of red blood cells: Progress and problems. Physiol. Rev. 1988, 68, 503-554.

148. Friederichs, E.; Meiselman, H.J. Effects of calcium permeabilization on RBC rheologic behavior. Biorheology 1994, 31, 207-215.

149. Bosman, G.J.; Willekens, F.L.; Werre, J.M. Erythrocyte aging: A more than superficial resemblance to apoptosis? Cell Physiol. Biochem. 2005, 16, 1-8.

150. Mohandas, N.; Groner, W. Cell membrane and volume changes during red cell development and aging. Ann. N. Y. Acad. Sci. 1989, 554, 217-224.

151. Lutz, H.U. Innate immune and non-immune mediators of erythrocyte clearance. Cell. Mol. Biol. (Noisy-le-grand) 2004, 50, 107-116.

152. Lew, V.L.; Daw, N.; Etzion, Z.; Tiffert, T.; Muoma, A.; Vanagas, L.; Bookchin, R.M. Effects of age-dependent membrane transport changes on the homeostasis of senescent human red blood cells. Blood 2007, 110, 1334-1342.

153. Rice, L.; Alfrey, C.P. The negative regulation of red cell mass by neocytolysis: Physiologic and pathophysiologic manifestations. Cell Physiol. Biochem. 2005, 15, 245-250.

154. Risso, A.; Turello, M.; Biffoni, F.; Antonutto, G. Red blood cell senescence and neocytolysis in humans after high altitude acclimatization. Blood Cells Mol. Dis. 2007, 38, 83-92.

155. Chang, C.-C.; Chen, Y.; Modi, K.; Awar, O.; Alfrey, C.; Rice, L. Changes of red blood cell surface markers in a blood doping model of neocytolysis. J. Investig. Med. 2009, 57, 650-654.

156. Nguyen, D.B.; Wagner-Britz, L.; Maia, S.; Steffen, P.; Wagner, C.; Kaestner, L.; Bernhardt, I. Regulation of phosphatidylserine exposure in red blood cells. Cell Physiol. Biochem. 2011, 28, 847-856.

157. Eaton, J.W.; Skelton, T.D.; Swofford, H.S.; Kolpin, C.E.; Jacob, H.S. Elevated erythrocyte calcium in sickle cell disease. Nature 1973, 246, 105-106.

158. Etzion, Z.; Tiffert, T.; Bookchin, R.M.; Lew, V.L. Effects of deoxygenation on active and passive $\mathrm{Ca}^{2+}$ transport and on the cytoplasmic $\mathrm{Ca}^{2+}$ levels of sickle cell anemia red cells. J. Clin. Invest. 1993, 92, 2489-2498.

159. Joiner, C.H.; Jiang, M.; Franco, R.S. Deoxygenation-induced cation fluxes in sickle cells. IV. Modulation by external calcium. Am. J. Physiol. 1995, 269, C403-C409.

160. Wiley, J.S. Increased erythrocyte cation permeability in thalassemia and conditions of marrow stress. J. Clin. Invest. 1981, 67, 917-922.

161. Shalev, O.; Mogilner, S.; Shinar, E.; Rachmilewitz, E.A.; Schrier, S.L. Impaired erythrocyte calcium homeostasis in beta-thalassemia. Blood 1984, 64, 564-566.

162. Bookchin, R.M.; Ortiz, O.E.; Shalev, O.; Tsurel, S.; Rachmilewitz, E.A.; Hockaday, A.; Lew, V.L. Calcium transport and ultrastructure of red cells in beta-thalassemia intermedia. Blood 1988, 72, 1602-1607.

163. Sabina, R.L.; Waldenström, A.; Ronquist, G. The contribution of $\mathrm{Ca}+$ calmodulin activation of human erythrocyte AMP deaminase (isoform E) to the erythrocyte metabolic dysregulation of familial phosphofructokinase deficiency. Haematologica 2006, 91, 652-655.

164. Bookchin, R.M.; Ortiz, O.E.; Somlyo, A.V.; Somlyo, A.P.; Sepulveda, M.I.; Hockaday, A.; Lew, V.L. Calcium-accumulating inside-out vesicles in sickle cell anemia red cells. Trans. Assoc. Am. Phys. 1985, 98, 10-20. 
165. Lew, V.L.; Hockaday, A.; Sepulveda, M.I.; Somlyo, A.P.; Somlyo, A.V.; Ortiz, O.E.; Bookchin, R.M. Compartmentalization of sickle-cell calcium in endocytic inside-out vesicles. Nature 1985, 315, 586-589.

166. Eaton, W.A.; Hofrichter, J. Sickle cell hemoglobin polymerization. Adv. Protein Chem. 1990, 40, 263-279.

167. Vandorpe, D.H.; Xu, C.; Shmukler, B.E.; Otterbein, L.E.; Trudel, M.; Sachs, F.; Gottlieb, P.A.; Brugnara, C.; Alper, S.L. Hypoxia activates a $\mathrm{Ca}^{2+}$-permeable cation conductance sensitive to carbon monoxide and to GsMTx-4 in human and mouse sickle erythrocytes. PLoS One 2010, 5 , e8732.

168. Ortiz, O.E.; Lew, V.L.; Bookchin, R.M. Calcium accumulated by sickle cell anemia red cells does not affect their potassium $(86 \mathrm{Rb}+)$ flux components. Blood 1986, 67, 710-715.

169. Rhoda, M.D.; Apovo, M.; Beuzard, Y.; Giraud, F. $\mathrm{Ca}^{2+}$ permeability in deoxygenated sickle cells. Blood 1990, 75, 2453-2458.

170. Clark, M.R.; Rossi, M.E. Permeability characteristics of deoxygenated sickle cells. Blood 1990, 76, 2139-2145.

171. De Franceschi, L.; Franco, R.S.; Bertoldi, M.; Brugnara, C.; Matte, A.; Siciliano, A.; Wieschhaus, A.J.; Chishti, A.H.; Joiner, C.H. Pharmacological inhibition of calpain-1 prevents red cell dehydration and reduces Gardos channel activity in a mouse model of sickle cell disease. FASEB J. 2013, 27, 750-759.

172. Siciliano, A.; Turrini, F.; Bertoldi, M.; Matte, A.; Pantaleo, A.; Olivieri, O.; de Franceschi, L. Deoxygenation affects tyrosine phosphoproteome of red cell membrane from patients with sickle cell disease. Blood Cells Mol. Dis. 2010, 44, 233-242.

173. Rank, B.H.; Hebbel, R.P.; Carlsson, J. Oxidation of membrane thiols in sickle erythrocytes. Prog. Clin. Biol. Res. 1984, 165, 473-477.

174. Wood, K.C.; Hebbel, R.P.; Lefer, D.J.; Granger, D.N. Critical role of endothelial cell-derived nitric oxide synthase in sickle cell disease-induced microvascular dysfunction. Free Radic. Biol. Med. 2006, 40, 1443-1453.

175. Hebbel, R.P. Perspectives series: Cell adhesion in vascular biology. Adhesive interactions of sickle erythrocytes with endothelium. J. Clin. Invest. 1997, 99, 2561-2564.

176. Antonelou, M.H.; Tzounakas, V.L.; Velentzas, A.D.; Stamoulis, K.E.; Kriebardis, A.G.; Papassideri, I.S. Effects of pre-storage leukoreduction on stored red blood cells signaling: A time-course evaluation from shape to proteome. J. Proteomics 2012, 76, 220-238.

177. Schrier, S.L.; Sohmer, P.R.; Moore, G.L.; Ma, L.; Junga, I. Red blood cell membrane abnormalities during storage: Correlation with in vivo survival. Transfusion 1982, 22, 261-265.

178. Wolfe, L. The red cell membrane and the storage lesion. Clin. Haematol. 1985, 14, 259-276.

179. Chin-Yee, I.H.; Gray-Statchuk, L.; Milkovich, S.; Ellis, C.G. Transfusion of stored red blood cells adhere in the rat microvasculature. Transfusion 2009, 49, 2304-2310.

180. Chaudhary, R.; Katharia, R. Oxidative injury as contributory factor for red cells storage lesion during twenty eight days of storage. Blood Transfus. 2012, 10, 59-62.

181. Kaestner, L.; Juzeniene, A.; Moan, J. Erythrocytes-the "house elves" of photodynamic therapy. Photochem. Photobiol. Sci. 2004, 3, 981-989. 
182. Kaestner, L. Evaluation of human erythrocytes as model cells in photodynamic therapy. Gen. Physiol. Biophys. 2003, 22, 455-465.

183. Muller, O.; Tian, Q.; Zantl, R.; Kahl, V.; Lipp, P.; Kaestner, L. A system for optical high resolution screening of electrical excitable cells. Cell Calcium 2010, 47, 224-233.

184. Kaestner, L. Calcium Signalling. Approaches and Findings in the Heart and Blood; Springer: Heidelberg, Germany, 2013.

185. Minetti, G.; Egée, S.; Mörsdorf, D.; Steffen, P.; Makhro, A.; Achilli, C.; Ciana, A.; Wang, J.; Bouyer, G.; Bernhardt, I.; et al. Red cell investigations: Art and artefacts. Blood Rev. 2013, 27, 91-101.

186. Wang, J.; Wagner-Britz, L.; Bogdanova, A.; Ruppenthal, S.; Wiesen, K.; Kaiser, E.; Tian, Q.; Krause, E.; Bernhardt, I.; Lipp, P.; et al. Morphologically homogeneous red blood cells present a heterogeneous response to hormonal stimulation. PLoS One 2013, submitted for publication.

(C) 2013 by the authors; licensee MDPI, Basel, Switzerland. This article is an open access article distributed under the terms and conditions of the Creative Commons Attribution license (http://creativecommons.org/licenses/by/3.0/). 